\title{
DUE PROCESS AT SENTENCING: IMPLEMENTING THE RULE OF UNITED STATES V. TUCKER
}

In United States v. Tucker, ${ }^{1}$ the Supreme Court held that a criminal defendant's sentence is constitutionally invalid if its length was enhanced by the sentencing court's consideration of prior convictions that are later found unconstitutional under Gideon v. Wainwright. ${ }^{2}$ In attempting to implement this rule, the courts of appeals have not agreed on the proper procedures and standards for a Tucker challenge to a sentence. This Comment will discuss possible approaches to the three most troublesome issues posed by Tucker: (1) the proper procedure for invalidating a prior conviction under Gideon; (2) the proper standard for determining whether a sentencing judge sufficiently relied upon prior invalid convictions so as to require vacating the sentence; (3) the proper remedy for a Tucker violation, once established. Although the Tucker problem can theoretically arise in various combinations of state and federal jurisdictions, ${ }^{3}$ this Comment will discuss the problem only in the most recurrent context - where a federal sentence is enhanced by consideration of invalid prior state convictions, and the federal prisoner challenges his sentence in the federal court that sentenced him under 28 U.S.C. section $2255(1970){ }^{4}$

1404 U.S. 443 (1972).

2372 U.S. 335 (1963). Gideon held that a criminal defendant has a right to the assistance of counsel at trial and that the states must provide counsel for indigents upon request.

${ }^{3}$ For example, the enhanced sentence may have been imposed by a state court, in which case it must be challenged under 28 U.S.C. $\$ 2254(1970)$, which requires prior exhaustion of state remedies. Or, the allegedly invalid prior convictions may have been federal, not state. These and other variations of the Tucker scenario will not be discussed herein.

4 The statute reads, in relevant part:

A prisoner in custody under sentence of a court established by Act of Congress claiming the right to be released upon the ground that the sentence was imposed in violation of the Constitution or laws of the United States, . . . or that the sentence was in excess of the maximum authorized by law, or is otherwise subject to collateral attack, may move the court which imposed the sentence to vacate, set aside or correct the sentence.

A motion for such relief may be made at any time.

Unless the motion and the files and records of the case conclusively show that the prisoner is entitled to no relief, the court shall cause notice thereof to 


\section{History of the Case}

On May 20, 1953, Forrest S. Tucker was found guilty by a California federal district court of armed robbery. He was sentenced to twenty-five years' imprisonment, the maximum term authorized by the federal statute. ${ }^{5}$ During the course of the trial, the prosecution was permitted to ask Tucker on cross-examination for impeachment purposes whether he had any prior felony convictions. Tucker admitted to three such convictions.

Several years later, the Superior Court of Alameda County, California, conclusively determined in a collateral proceeding that Tucker's 1938 conviction in Florida and his 1946 conviction in Louisiana were invalid because in both cases he had not been assisted by counsel and had not waived his right to such assistance. ${ }^{6}$

In 1969, Tucker filed a motion under 28 U.S.C. section $2255^{7}$ requesting the sentencing district court to vacate the judgment and set aside the sentence. The conviction was alleged to be invalid under Burgett $v$. Texas ${ }^{8}$ in that evidence of prior uncounseled convictions was admitted for impeachment purposes. The district court denied the motion, finding that, although admission of the evidence of the convictions was error, in light of the overwhelming evidence of guilt the admission constituted harmless error under the standard of Chapman $v$. Califormia. ${ }^{9}$

The Court of Appeals for the Ninth Circuit affirmed the district court's holding that the use of the evidence to impeach the defendant's credibility was precluded by Burgett and approved the district court's finding that the error was "harmless

be served upon the United States attorney, grant a prompt hearing thereon, determine the issues and make findings of fact and conclusions of law with respect thereto. If the court finds . . that the sentence imposed was not authorized by law or otherwise open to collateral attack, or that there has been such a denial or infringement of the constitutional rights of the prisoner as to render the judgment vulnerable to collateral attack, the court shall vacate and set the judgment aside and shall discharge the prisoner or resentence him ... or correct the sentence as may appear appropriate.

${ }^{5}$ See 18 U.S.C. $\S 2113$ (d) (1970).

${ }^{6}$ This decision is unreported, but its accuracy was accepted by the Supreme Court in United States v. Tucker, 404 U.S. 443, $445 \mathrm{n} .2$ (1972).

728 U.S.C. \& 2255 (1970). See note 4 supra.

${ }^{8} 389$ U.S. 109 (1967). The Court held that the introduction of evidence of prior uncounseled convictions for the purpose of supporting a conviction was reversible error. In a much-quoted phrase the Court stated that " $[t] 0$ permit a conviction obtained in violation of Gideon v. Wainwright to be used against a person either to support guilt or enhance punishment for another offense . . . is to erode the principle of that case." Id. at 115 (citation omitted).

${ }^{9} 386$ U.S. 18 (1967). Under Chapman, before a constitutional error may be deemed harmless, it must be shown that the error did not contribute to the verdict. 
beyond a reasonable doubt."10 The appellate court went on to find, however, that there existed "a reasonable probability that the defective prior convictions may have led the trial court to impose a heavier prison sentence than it otherwise would have imposed. Therefore, as to the sentencing, we are unable to conclude that the reception of such evidence was harmless beyond a reasonable doubt."11 Accordingly, the district court's refusal to invalidate the conviction was affirmed but the case was remanded for "resentencing without consideration of any prior convictions which are invalid under Gideon v. Wainwright ...."12

Affirming the holding of the Ninth Circuit, the Supreme Court elaborated on the rationale. The Court acknowledged that under the federal judicial system a trial judge generally has great latitude in sentencing and "may appropriately conduct an inquiry broad in scope, largely unlimited either as to the kind of information he may consider, or the source from which it may come."13 Furthermore, the Court agreed with the Government that "a sentence imposed by a federal district judge, if within statutory limits, is generally not subject to review."14

Notwithstanding its acknowledgment of wide judicial discretion, the Court held that Tucker required a limiting of this sentencing latitude for two reasons. First, the sentence was "founded at least in part upon misinformation of constitutional magnitude. ... [T] $[\mathrm{T}$ his prisoner was sentenced on the basis of assumptions concerning his criminal record which were materially untrue'."15 Secondly, as Burgett had noted, to allow such a sentence to stand would erode the Gideon rule. ${ }^{16}$ The Court in Burgett recognized that "since the defect in the prior conviction was denial of the right to counsel, the accused in effect suffers anew from the deprivation of the Sixth Amendment right." 17

${ }^{10}$ Tucker v. United States, 431 F.2d 1292, 1293 (9th Cir. 1970).

"Id. at 1294.

12 Id. (citation omitted).

${ }^{13}$ United States v. Tucker, 404 U.S. 443, 446 (1972) (citation omitted).

${ }^{14}$ Id. at 447. This dictum has become perhaps as important and noted as the ultimate holding. It has been cited in numerous cases denying appellate review of sentences. See, e.g., United States v. Glazer, 532 F.2d 224, 231 (2d Cir. 1976); United States v. Wilkinson, 513 F.2d 227, 234 (7th Cir. 1975); United States v. Anderson, 466 F.2d 1361 (8th Cir.), cert. denied, 405 U.S. 918 (1972).

15404 U.S. at 447 (quoting Townsend v. Burke, 334 U.S. 736, 741 (1948)). The Court further noted: "The record . . . makes evident that the sentencing judge gave specific consideration to the respondent's previous convictions before imposing sentence on him." Id.

${ }^{16} I d$. at 449.

${ }^{17}$ Burgett v. Texas, 389 U.S. 109, 115 (1967). 
In light of this reasoning, the Court asserted that whether the outcome of Tucker's prior convictions would have been affected by assistance of counsel was irrelevant. The relevant question was instead whether Tucker's sentence "might have been different if the sentencing judge had known that at least two of the respondent's previous convictions had been unconstitutionally obtained." 18 The Court concluded that "the factual circumstances of the respondent's background would have appeared in a dramatically different light at the sentencing proceeding,"19 had the trial judge known that Tucker's prison record reflected unconstitutional confinement rather than valid convictions. Furthermore, the Court disagreed with the Government's contention that a "re-evaluation of the respondent's sentence by the District Court . . . will be either 'artificial' or 'unrealistic'." 20 The case was remanded to the trial court for "reconsideration" of the sentence. $^{21}$

The Tucker rule that it is impermissible for a court to enhance a defendant's sentence on the basis of past convictions which are unconstitutional under Gideon supports two observations about Tucker violations. First, the sentencing judge must have explicit knowledge of the convictions which later prove to be invalid for there to be a Tucker violation. Otherwise, he could not be said to rely upon those convictions in his own sentencing decision. A less obvious inference is that the sentencing judge must be unaware of the constitutional invalidity of the prior convictions. This inference stems from the Court's statement that Tucker's record would not have had the same impact on the trial judge had he known of the defects in the prior convictions. ${ }^{22}$ Tucker recognized that the judge's inquiry is

${ }^{18}$ United States v. Tucker, 404 U.S. 443,448 (1972).

${ }^{19} \mathrm{Id}$.

${ }^{20} I d$. at 448-49. The Court stated that although the use of the convictions to support guilt was "harmless error," it did not necessarily follow that the judge, had he known the true nature of respondent's record, would nonetheless have imposed the maximum sentence. Furthermore, "[i]t would be equally callous to assume . . that the trial judge will upon reconsideration 'undoubtedly' impose the same sentence he imposed in 1953." Id. at 449 n.8.

${ }^{21} \mathrm{Id}$. at 449 . For a discussion of the relative merits of reconsideration and resentencing as remedies for a Tucker violation, see text accompanying notes 79-88 infra.

${ }^{22}$ See text accompanying note 19 supra. Such an inference is also supported by Williams v. New York, 337 U.S. 241 (1949), where the Court held that a sentencing judge may consider relevant and reliable information of criminal activities of the defendant even where he was never brought to trial. This rule has been extended to cases in which the defendant was brought to trial and acquitted. See, e.g., United States v. Sweig, 454 F.2d 181 (2d Cir. 1972). In United States v. Atkins, 480 F.2d 1223, 1224 (9th Cir. 1973), the Ninth Circuit asserted that "the mere fact that an invalid conviction was obtained does not immunize the facts underlying this conviction from consideration 
"largely unlimited either as to the kind of information he may consider, or the source from which it may come." 23 Therefore a sentencing judge may consider prior convictions and other evidence of criminal activities. By the same token, however, his assessment should be tempered by any knowledge of constitutional violations involved in obtaining those convictions. As the First Circuit stated in United States $v$. Sawaya, "Tucker does not hold that sentencing judge may not be aware of prior convictions, even constitutionally infirm ones. It holds only that the court must be aware of the infirmities." 25

The second requirement for a Tucker violation is that the sentencing judge's knowledge of the prior convictions might have increased the length of the sentence. The possibility of a sentencing judge's consideration of prior convictions in his own decision is a necessary element of a Tucker violation. Whether the standard of causation is the minimal "might have" standard or some stricter standard is unresolved and will be discussed later in further detail. ${ }^{26}$

\section{Determining the Invalidity of Prior Convictions}

In Tucker itself, the petitioner's prior Florida and Louisiana convictions had been invalidated by a California court before he brought his section 2255 motion. The Supreme Court was therefore not faced with the issue of whether federal courts must require petitioners to have allegedly unconstitutional convictions invalidated before filing Tucker petitions. In later cases, however, petitioners have brought motions merely alleging that their prior state convictions were invalid. ${ }^{27}$ The courts of appeals have differed in their treatment of such motions. The majority of the circuits have allowed the federal judge in the district where the motion is brought to hold a hearing to determine the validity of the challenged convictions. ${ }^{28}$ The rest of the circuits have re-

of the sentencing judge." But the court acknowledged that a sentencing court may not give weight to such convictions without also considering the fact and effect of unconstitutionality. Id.

23404 U.S. at 446.

${ }^{24} 486$ F.2d 890 (1st Cir. 1973).

${ }^{25} \mathrm{Id}$. at 893 .

${ }^{26}$ See text accompanying notes 66-78 infra.

${ }^{27}$ See, e.g., United States ex rel. Fletcher v. Walters, 526 F.2d 359 (3d Cir. 1975); Crovedi v. United States, 517 F.2d 541 (7th Cir. 1975); Wilson v. United States, 504 F.2d 59 (6th Cir. 1974); Wilsey v. United States, 496 F.2d 619 (2d Cir. 1974); United States v. Sawaya, 486 F.2d 890 (1st Cir. 1973); Brown v. United States, 483 F.2d 116 (4th Cir. 1973); Lipscomb v. Clark, 468 F.2d 1321 (5th Cir. 1972).

${ }^{28}$ See, e.g., Reynolds v. United States, 528 F.2d 461 (6th Cir. 1976) (per curiam); 
quired the petitioner to invalidate each of the challenged convictions in the state in which it occurred before a section 2255 motion will be entertained. ${ }^{29}$ Whether such a requirement should be imposed depends upon the practical ramifications for Tucker petitioners, for federal courts hearing section 2255 motions, and for state courts that imposed the now-challenged convictions.

\section{A. Brown and the Prior Invalidation Requirement}

The leading case requiring invalidation of the jurisdiction of the prior conviction is Brown v. United States. ${ }^{30}$ In Brown, the Fourth Circuit reasoned that a collateral proceeding should not be premised upon a collateral attack on another conviction, particularly one imposed by a state court of foreign jurisdiction. Otherwise, "a petitioner might use a collateral proceeding in one jurisdiction to make 'a collateral second-level' attack on judgments of convictions rendered in state courts in which there had been not the slightest attempt at exhaustion of state remedies." ${ }^{11}$ The court further stated:

If the state conviction is in another state from that in which the 2255 proceedings are had, the State procuring the challenged conviction would not be a party to the proceeding, would not have been heard on the invalidation of its conviction, and would have been denied the right to a prior exhaustion of state remedies as required under Section 2254(b), 28 U.S.C. ${ }^{32}$

Practical efficiency also called for requiring each prior conviction to be invalidated in the state that imposed it. The court stated that "it can hardly be gainsaid that a more orderly and justiciable review of the validity of a conviction can be afforded by the sentencing court than by a court of a foreign jurisdiction ..."33

United States ex rel. Fletcher v. Walters, 526 F.2d 359 (3d Cir. 1975); Crovedi v. United States, 517 F.2d 541 (7th Cir. 1975); Wilsey v. United States, 496 F.2d 619 (2d Cir. 1974); Leano v. United States, 494 F.2d 361 (9th Cir. 1974); United States v. Sawaya, 486 F.2d 890 (Ist Cir. 1973); Mitchell v. United States, 482 F.2d 289 (5th Cir. 1973).

${ }^{29}$ See, e.g., Young v. United States, 485 F.2d 292 (8th Cir. 1973), cert. denied, 416 U.S. 971 (1974); Brown v. United States, 483 F.2d 116 (4th Cir. 1973).

${ }^{30} 483$ F.2d 116 (4th Cir. 1973). It is not clear whether the Fourth Circuit's rule requires invalidation before the district court rules on the appropriateness of the sentence, or merely before final relief can be granted. Compare Brown v. United States with United States v. Dorman, 496 F.2d 438 (4th Cir.), cert. denied, 419 U.S. 945 (1974).

${ }^{31} 483$ F.2d at 118.

32 Id. at 119.

${ }^{33}$ Id. Mr. Justice Rehnquist, dissenting in Loper v. Beto, 405 U.S. 473 (1972), 
The Fourth Circuit recognized that requiring invalidation by the prior-conviction court was inconsistent with the procedure that the circuit courts had ordinarily used when dealing with recidivist or second-offender statutes. Recidivist statutes allow the imposition of sentences beyond the ordinary maximum for defendants with prior convictions of certain crimes. In cases involving such sentencing procedures, the collateral-attack court is generally permitted to determine the validity of the prior convictions. ${ }^{34}$ The Brown court, however, distinguished these cases on the grounds that the existence of prior valid convictions was a necessary element of a recidivist or second-offender conviction that had to be proven by the prosecution. ${ }^{35}$ The court

which held that the use of convictions that are invalid under Gideon to impeach a defendant's credibility was reversible error, displayed the same concern. He wrote:

It is a sufficiently difficult task for a federal district court sitting in Texas to review a Texas state criminal proceeding for constitutional error; in that case the Texas state custodian himself is a defendant in the proceeding, all counsel and the district judge are familiar with local Texas criminal procedure, and the State and petitioners both have available such witnesses as may be necessary to augment the record pertaining to the judgment under attack. Whatever evidentiary hearing is held will take place in the general locale where those witnesses who have knowledge of the earlier state proceedings are available to testify.

It is a good deal more difficult for the same Texas habeas court to make a second-level collateral review of judgments of conviction rendered in the state courts of Mississippi and Tennessee. The States that rendered the convictions are not parties to the Texas habeas proceeding, and, of course, have no interest whatever in sustaining the validity of sentences long since served. Neither the Texas District Court nor Texas counsel can be expected to have any familiarity with the vagaries of criminal procedure in Mississippi and Tennessee. If there are any surviving witnesses to the actual court proceedings which took place from 30 to 40 years ago, they are sufficiently distant from the location of the Texas habeas court as to render their voluntary appearance unlikely, and their compulsion by process impossible.

405 U.S. at 500.

${ }^{34}$ E.g., Taylor v. United States, 472 F.2d 1178 (8th Cir. 1973); United States ex rel. Lasky v. Lavallee, 472 F.2d 960 (2d Cir. 1973); Williams v. Coiner, 392 F.2d 210 (4th Cir. 1968).

${ }^{35}$ The court stated:

The very right of the Government to convict the defendant under these statutes and to impose sentence thereunder is dependent on the ability of the state to prove that there were constitutionally valid prior convictions. In such a context, the defendant is manifestly entitled to be heard at the time in the trial court on the constitutional validity of those prior convictions and the trial court is obligated, as a condition to its exercise of power under the statute, to rule whether the defendant has been previously sentenced under a constitutionally valid conviction. . . . The Court cannot, in this posture of the case, stay the prosecution until state remedies are exhausted; it must rule on the record of conviction as it is offered in evidence. By the same token, when that conviction is assailed later in post-conviction proceedings, it must be tested by the trial record itself; and, since at trial no exhaustion of state remedies is required, 
pointed out that in most recidivist cases, the record of conviction was silent as to the presence of counsel, thereby invoking a presumption of invalidity unless the state could affirmatively show that the defendant waived counsel in the prior convictions. In such cases, "the court is not invalidating the recidivist conviction itself because the latter rests on evidence constitutionally invalid, i.e., on a prior state conviction which on its face is void under Gideon."36

The majority rationale in Brown was premised on considerations of conserving judicial resources, practical efficiency, and the distinction between Tucker cases and the ordinary recidivist situation. The validity of each premise is questionable, however. Judge Craven, dissenting in part in Brown, disagreed with the majority's requirement of invalidation by the prior-conviction court. First, he stated that to allow the collateral-attack court to make the determination would in fact conserve judicial resources. ${ }^{37}$ The Fourth Circuit's rule would require the petitioner to file collateral attacks in each state that had imposed a challenged conviction. If successful, the petitioner would still have to resort to the federal court hearing the section $2255 \mathrm{mo}$ tion for the appropriate relief. "Moving a stack of petitions to some other court," the dissent noted, "does not really advance the judicial process." 38 Second, Judge Craven disputed the practical efficiency argument, pointing out that "[d]etermining the presence of counsel is not a complex issue."39 Finally, he stated that the court's differentiation between recidivist and secondoffender cases on the one hand, and the usual Tucker cases on the other was "a distinction but without a difference: enhanced punishment rests upon a prior criminal record rendered void by Gideon." 40

The distinction drawn by Brown between cases involving re-

similarly the post-conviction remedy does not require exhaustion.

483 F.2d at 121 (citations omitted).

${ }^{36}$ Id. (footnote omitted).

${ }^{37} I d$. at 122 (Craven, J., dissenting).

${ }^{38} I d$.

${ }^{39} I d$. This opinion has been echoed by Mr. Justice Douglas: "The determination whether a defendant had counsel at the time of prior convictions should ordinarily be ascertainable from an examination of the records of conviction." Dorman v. United States, 419 U.S. 945, 946 (1974) (Douglas, J., dissenting from the denial of certiorari).

Where it is unclear whether petitioner had a right to counsel under the circumstances, the Gideon question may not be capable of resolution on the face of the record. See Argersinger v. Hamlin, 407 U.S. 25 (1972); United States v. Sawaya, 486 F.2d 890, 892 (1st Cir. 1973).

${ }^{40} 483$ F.2d at 123. 
cidivist or second offender statutes and the ordinary Tucker situation is more of form than of substance. A recidivist statute is more like a sentencing regulation than a substantive criminal statute. In both the recidivist and Tucker cases, a prior conviction is used to enhance the defendant's sentence. In both cases, the underlying convictions are being challenged only as to their present use for enhancement purposes. The original sentences in these cases will probably have been served, ${ }^{41}$ and the states that imposed them will have little interest in defending them. Because of these similarities, courts may apply to Tucker situations the same sort of invalidation requirements used in recidivist cases.

Courts dealing with recidivist sentences on collateral attack have rejected the requirement of prior invalidation of state convictions by the same courts which imposed them. The Fifth Circuit in Craig v. Beto, ${ }^{42}$ citing Burgett v. Texas, ${ }^{43}$ said that the sentencing state "cannot disregard the constitutional infirmities of any conviction which it seeks to use for enhancement purposes." 44 The court found two reasons justifying challenges of state convictions on federal collateral attack. First, a petitioner would not have been serving the sentence but for the prior invalid conviction. Secondly, favorable results in the state courts would still require a petitioner to return for further proceedings in the federal court. ${ }^{45}$ In a statement as applicable to the usual Tucker situation as to the recidivist case, the court said:

Since our decision only relates to the use of that [Oklahoma] conviction in a Texas Court, it is only necessary that Texas state remedies be exhausted. Our action will leave standing the conviction in Oklahoma, as far as Oklahoma is concerned, so that it is not necessary for Craig to show that he has exhausted the postconviction remedies that might have been available in that state. ${ }^{46}$

In Lipscomb \%. Clark, ${ }^{47}$ the Fifth Circuit applied this rationale to a non-recidivist situation and did not require the petitioner to

${ }^{41}$ This would appear to be true because if the sentences had not been served, petitioners would be eager to attack them in the jurisdictions which imposed them.

42458 F.2d 1131 (5th Cir. 1972).

13389 U.S. 109 (1967); see note 8 supra.

44458 F.2d at 1133.

45 Id. at 1134 .

${ }^{16} \mathrm{Id}$.

${ }^{47} 468$ F.2d 1321 (5th Cir. 1972). 
invalidate his prior convictions in state court. While recognizing the factual distinction from the situation in Tucker itself, the court stated:

The primary difference between the facts in Tucker and this case is that in Tucker the unconstitutionality of the prior convictions had been fully adjudicated in the state courts. Here there is only Lipscomb's allegation that the priors were obtained in violation of Gideon. The Solicitor General did not find this distinction sufficient to place this case outside the scope of Tucker. We agree. $^{48}$

Accordingly, the court gave instructions that the district court should hold evidentiary hearings and determine the constitutionality of the petitioner's prior convictions. ${ }^{49}$

Other circuits have rejected the Brown rationale and implemented procedures similar to those used in recidivist cases for authorizing federal district courts to determine the validity of prior convictions. The Seventh. Circuit in Crovedi v. United States, ${ }^{50}$ while recognizing "conceptual differences" between the recidivist situation and the "collateral attack aspects" inherent in a Tucker claim of enhancement of sentence because of consideration of prior invalid convictions, nevertheless held that "the differences are of insufficient magnitude for us to repudiate this court's holding in Lufman that we are here dealing with a conviction which, if unconstitutionally obtained, is infirm from its incipiency." 51 The court accordingly remanded to the district court to determine the validity of the prior convictions. ${ }^{52}$

${ }^{48}$ Id. at 1323. The Solicitor General had joined with Lipscomb's petition for certiorari which was ultimately denied in Lipscomb v. United States, 404 U.S. 1021 (1972), urging that the case be remanded to the district court in light of Tucker. Although the Supreme Court also denied a petition for rehearing, 406 U.S. 911 (1972), the Fifth Circuit took the opportunity to consider the claim in light of Tucker.

49468 F.2d at 1323.

so 517 F.2d 541 (7th Cir. 1975).

${ }^{51} I d$. at 546. United States v. Lufman, 457 F.2d 156 (7th Cir. 1972), was a recidivist case holding that if the petitioner challenges a prior conviction and the record is silent, then the government must affirmatively show presence of counsel or explicit waiver of the right to counsel.

32 All but two of the circuits apparently have assumed that the district court judge has the power to decide the constitutionality of the prior convictions, and have merely remanded the cases to the collateral-attack courts with instructions to do so. See, e.g., Wilsey v. United States, 496 F.2d 619 (2d Cir. 1974); Leano v. United States, 494 F.2d 361 (9th Cir. 1974); United States v. Sawaya, 486 F.2d 890 (1st Cir. 1973). The Court of Appeals for the District of Columbia has never faced the Tucker issue directly and the Tenth Circuit has rarely done so. In Martinez v. United States, 464 F.2d 1289 (10th Cir. 1972), the Tenth Circuit, in a second-offender situation where the prior conviction 


\section{B. Discarding the Requirement of Prior Invalidation}

In addition to the reasons given by the Fifth and Seventh Circuits for repudiating the Brown rationale of requiring prior invalidation of state convictions, other policy considerations favor the rejection of such a rule. The ability of the federal courts to determine Gideon violations in past convictions, the partial absence of justifications that underlie the normal exhaustion of remedies requirement, ${ }^{53}$ and the tremendous burden that the rule would place upon petitioners call for its abandonment.

The determination of whether petitioner had counsel, as Judge Craven stated, "is not a complex issue."54 A foreign federal district court would be as qualified as a foreign state's lower court to make such a review. Barring the impeachment of a defendant's credibility through the use of prior convictions that were invalid under Gideon, the Supreme Court in Loper v. Beto ${ }^{\mathbf{5 5}}$ strongly implied that the federal collateral-attack court could properly determine the validity of prior convictions. The Court reversed the district court's denial of relief, even though no state court had ever ruled on the validity of petitioner's convictions. The Court specifically noted that the validity of the challenged convictions had not yet been conclusively determined below, ${ }^{56}$ but remanded to the court of appeals without any instruction to require state invalidation.

The policies ordinarily advanced for the requirement that petitioners exhaust their available state remedies before proceeding to a federal collateral-attack court are federal-state comity, ${ }^{57}$

was facially invalid (marijuana tax law violation), remanded for resentencing without consideration of the invalid sentence.

${ }^{53}$ It should be noted that the exhaustion doctrine is directly related to the Tucker-like situation in which the challenged sentence was imposed by a state court rather than by a federal court. In that situation, which is not addressed in this Comment, 28 U.S.C. $\S 2254$ (1970) expressly requires the exhaustion of available, effective state remedies as a condition precedent to obtaining habeas corpus relief from the federal court.

${ }^{54}$ Brown v. United States, 483 F.2d 116, 122 (4th Cir. 1973) (Craven, J., dissenting in part); see note 39 supra.

35405 U.S. 473 (1972).

${ }^{36} I d$. at 479 n.6. Mr. Justice White, concurring, explicitly stated that the court of appeals still needed to determine the validity of the prior conviction. Id. at 485 . Mr. Justice Rehnquist, in a sharp dissent, contended that the Court had failed to require prior invalidation-a step he believed to be a prerequisite for habeas relief. Id. at 497-503.

${ }^{57}$ See, e.g., Fay v. Noia, 372 U.S. 391, 419-20 (1963), quoting Darr v. Burford, 339 U.S. 200, 204 (1950): "it would be unseemly in our dual system of government for a federal district court to upset a state court conviction without an opportunity to the state courts to correct a constitutional violation ...." See also Rose v. Dickson, 327 F.2d 27, 28 (9th Cir. 1964). 
practical efficiency, ${ }^{58}$ encouraging state participation in shaping federal constitutional law, ${ }^{59}$ and reducing the caseload burden of the federal courts. ${ }^{60}$ These justifications are not as compelling in the Tucker context. Federal-state comity is not threatened by allowing federal courts to determine the validity of prior convictions because, as Mr. Justice Rehnquist observed, the states which originally obtained the convictions "have no interest whatever in sustaining the validity of sentences long since served." 61

Nor would such a determination pose practical problems for the federal courts, given the clear-cut standards for Gideon violations. ${ }^{62}$ An examination of the record would indicate whether counsel was present for the defendant and whether defendant had waived counsel. Moreover, because the Gideon rule is so firmly established, requiring state courts to invalidate their own convictions would not encourage state formulation of federal constitutional law. State courts would simply be applying a definitive test that leaves little room for substantive interpretation.

Nor would the litigation of such claims impose a tremen-

\footnotetext{
${ }^{58}$ See, e.g., Rose v. Dickson, 327 F.2d 27, 28 (9th Cir. 1964): "The issues presented often concern local attorneys and court personnel, and arise in a context of local procedures and practices, with which state courts are familiar. They may be resolved most effectively by those tribunals."

${ }^{59}$ See Amsterdam, Criminal Prosecutions Affecting Federally Guaranteed Civil Rights: Federal Removal and Habeas Corpus Jurisdiction to Abort State Court Trial, 113 U. PA. L. Rev. 793, 830-31 (1965). Professor Amsterdam asserts that

leaving federal defensive issues to the state criminal courts in the first instance gives those courts a promising opportunity for partnership in the administration of federal law. Hopefully, engagement in that partnership will cause the state courts to look upon the developing register of federal protections to the individual less as alien decrees imposed from distant Washington and more as indispensable conditions for the integrity of local justice, for which they bear responsibility.
}

${ }^{60}$ The rationale is that some petitioners will be released by the state before reaching federal court, or denied relief on adequate state grounds, or merely dissuaded from pursuing further their remedies. Moreover, federal questions may be clarified and factual determinations made, relieving the federal courts of some of their workload. See Amsterdam, supra note 59, at 831. See also Wade v. Mayo, 334 U.S. 672, 679-80 (1948), noting that "any other rule would visit upon the federal courts an impossible burden, forcing them to supervise the countless state criminal proceedings in which deprivations of federal constitutional rights are alleged."

${ }^{61}$ Loper v. Beto, 405 U.S. 473, 500 (1972) (Rehnquist, J., dissenting).

${ }^{62} \mathrm{See}$ text accompanying note 54 supra. The ability of federal courts to determine other constitutional violations in prior state convictions might be more questionable. For example, in the event that the Tucker rule were held to apply to sentences relying on prior convictions that were invalid under Miranda v. Arizona, 384 U.S. 436 (1966), a more extensive fact-finding would be required to determine the constitutionality of those convictions. Problems of retroactivity and harmless error complicate the application of the Tucker rule to other due process contexts, and will not be addressed in this Comment. 
dous burden on the federal courts. Petitioners' interest in attacking underlying convictions will be limited to those situations where such convictions have been used for enhancement purposes. ${ }^{63}$ The additional burden placed on federal courts by the limited number of Tucker cases is certainly outweighed by the tremendous burden which the prior invalidation rule would place on petitioners.

Requiring prior invalidation interferes with the exercise of the petitioner's constitutionally-mandated right to be resentenced under Tucker. The effect of such a rule would reduce the right to one in name only because the cost of obtaining relief would often be prohibitive. ${ }^{64}$ Where the underlying convictions are alleged to be invalid under Gideon, it is likely that many of the petitioners raising the issue will be indigent and unable to afford the expenses involved in invalidating the prior convictions. If a petitioner cannot afford counsel he will have to press his attack by himself unless he is fortunate enough to be in a state ${ }^{65}$ that provides free counsel to indigents in collateral proceedings. Even if he is not indigent, he may find the expenses prohibitive. Furthermore, if any of the convicting states require in-court appearances rather than the mere filing of papers, the petitioner may have to obtain separate local counsel in each of the jurisdictions. By contrast, only one attorney would be needed if the federal collateral-attack court were permitted to rule on the validity of the prior convictions. Another consideration of fairness to the petitioner would compel the least circuitous

${ }^{63}$ See text accompanying note 41 supra. The number of Tucker cases to date has been quite small and appears to be decreasing, given the nearly universal application of the Gideon rule today.

${ }^{64}$ Several courts have indeed taken into account such humane considerations in deciding not to require invalidation by the prior-conviction jurisdiction. In Mitchell v. United States, 482 F.2d 289 (5th Cir. 1973), the court recognized that "[a] requirement of exhaustion of collateral attack remedies in the state and federal courts where prior convictions were obtained would erect an insuperable barrier to effective implementation of the Tucker rule." Id. The number of proceedings, the expenses and difficulties involved in obtaining counsel, and the long delays would mean that "[e]xhaustion of the movant, rather than exhaustion of other collateral attack possibilities, would be the likely result." Id. at 294 . The court concluded, "We do not believe Tucker contemplated or is consistent with the creation of this type of procedural obstacle course." Id. In United States ex rel. Fletcher v. Walters, 526 F.2d 359, 362 (3d Cir. 1975), the Third Circuit echoed Mitchell in asserting that to require a petitioner to return to the states to invalidate each of the challenged prior convictions "would be to erect a high barrier to the effective vindication of his constitutional rights."

${ }^{65}$ A few states provide counsel to all indigents seeking post-conviction relief, and many provide counsel at the discretion of the court. See, e.g., Ill. Rev. Stat. ch. 38, § 122-4 (1973); Or. Rev. Stat. \& 138.590 (1975); Note, Prisoners' Rights-Access to Courts, 42 U. Colo. L. Rev. 275, 289 (1970). 
method of relief: the delay in obtaining relief may be so long that some of the unconstitutionally extended portion of the sentence will have been served before relief can be granted.

\section{Finding a TUCKER VIOLATION}

Just as the circuit courts have split on the question of which jurisdiction may invalidate the prior convictions, so do they disagree as to the standards for determining whether there has been sufficient reliance on an invalid conviction for the Tucker rule to apply. Two major approaches have been formulated: the reasonable probability or harmless error approach, and the general appropriateness test. In Tucker, the Supreme Court framed the test by asking whether Tucker's sentence "might have been different" had the sentencing judge known of the defects in the prior convictions. ${ }^{66}$ The court of appeals similarly observed that the record showed "a reasonable probability that the defective prior convictions may have led the trial court to impose a heavier prison sentence than it otherwise would have imposed. Therefore, as to the sentencing, we are unable to conclude that the reception of such evidence was harmless beyond a reasonable doubt."67 Both of these formulations appear to adopt the Supreme Court's general harmless error standard: the presentation must "prove beyond a reasonable doubt that the error complained of did not contribute to the verdict obtained." 68 The strict harmless error test of reliance would therefore require the invalidation of any sentence that might have been based upon consideration of a prior invalid conviction.

The other major test which has been adopted more or less by a majority of the circuits is the "general appropriateness" test adopted by the Fifth Circuit in Lipscomb v. Clark. ${ }^{69}$ Under Lipscomb, a district court hearing a Tucker petition must first determine "if, treating the state convictions alleged to have been unconstitutional as void and thus not to be considered in sentencing, [the challenged sentence] would still be the appropriate sentence based on the records of the trial and petitioner's ad-

${ }^{86} 404$ U.S. at 448.

${ }^{67}$ Tucker v. United States, 431 F.2d 1292, 1294 (9th Cir. 1970), aff'd, 404 U.S. 443 (1972).

${ }^{68}$ Chapman v. California, 386 U.S. 18, 24 (1967). The Ninth Circuit has usually applied this harmless error formula in alleged Tucker violations. E.g., Leano v. United States, 494 F.2d 361 (9th Cir. 1974); see Dukes v. United States, 492 F.2d 1187 (9th Cir. 1974); United States v. Eidum, 474 F.2d 581 (9th Cir. 1973). But see Wilson v. United States, 534 F.2d 130 (9th Cir. 1976).

${ }^{69} 468$ F.2d 1321 (5th Cir. 1972). 
justed conviction record."70 If the sentence would still be appropriate, the Tucker requirements are considered fulfilled, and the petitioner's quest for relief is terminated. ${ }^{71}$ If the sentence would no longer be appropriate, the district court then conducts an evidentiary hearing on the validity of the challenged prior convictions. If they are found to be invalid, the court "may then properly resentence" the petitioner. ${ }^{72}$ Thus, the Lipscomb standard allows a sentence to stand if it can still be called "appropriate," although the sentencing judge cannot say that consideration of the invalid convictions was "harmless" beyond a reasonable doubt.

Although this relatively permissive standard has been adopted, with some variations, by several circuits ${ }^{73}$ it should be rejected. Sentencing is a crucial step in the criminal adjudicatory process-indeed, for the large numbers of defendants who plead guilty ${ }^{74}$ it is the only step of any real consequence. The use of the strict harmless error test best safeguards the due process rights of defendants at this critical phase. When inadmissible evidence is admitted at trial before either judge or jury, the proper standard of review is harmless error. ${ }^{75}$ The same stan-

${ }^{70}$ Id. at 1323.

${ }^{71}$ Id. Although in Lipscomb the maximum sentence had been imposed, the court in Russo v. United States, 470 F.2d 1357, 1359 (5th Cir. 1972) noted that a Tucker petitioner's right to relief is not limited to cases in which the maximum sentence has been imposed.

${ }^{72} 468$ F.2d at 1323.

${ }^{73}$ E.g., Reynolds v. United States, 528 F.2d 461, 462 (6th Cir. 1976) (per curiam); Crovedi v. United States, 517 F.2d 541, 546 (7th Cir. 1975); United States v. Sawaya, 486 F.2d 890, 893 (1st Cir. 1973); McAnulty v. United States, 469 F.2d 254, 255 (8th Cir. 1972) (per curiam), cert. denied, 411 U.S. 949 (1973); cf. United States v. Radowitz, 507 F.2d 109, 112-13 (3d Cir. 1974) (affirming the district court's use of the Lipscomb procedure and re-imposition of original sentence after reconsideration of challenged sentence in light of alleged invalidity of prior state conviction); Hampton v. United States, 504 F.2d 600, 604 (10th Cir. 1974), cert. denied, 421 U.S. 917 (1975) (affirming re-imposition of same sentence upon district court's reconsideration of challenged sentence in light of alleged errors in presentence report's list of prior convictions). The Eighth Circuit's adherence to Lipscomb may be wavering. See, e.g., James v. United States, 476 F.2d 936 (8th Cir. 1973) (per curiam).

${ }^{74}$ See Note, Procedural Due Process at Judicial Sentencing for Felony, 81 HARv. L. REv. 821,821 n.1 (1968).

${ }^{75}$ The harmless error test that this Comment proposes be employed for finding Tucker violations is referred to throughout as the "strict harmless error test" to distinguish it from other, less satisfactory harmless error tests that may currently exist. For example, one commentator has suggested that there are three such tests. See Field, Assessing the Harmlessness of Federal Constitutional Error-A Process in Need of a Rationale, 125 U. PA. L. REv. 15 (1976). One of them-the overwhelming evidence test-resembles the Lipscomb general appropriateness test, and, for the reasons discussed in this Comment, is unsatisfactory in the Tucker situation. This Comment adopts the more traditional might-have-affected test as the "strict harmless error test." 
dard should apply when improper evidence is considered during sentencing.

The general appropriateness test is unsuitable because it fails to address the key issue underlying Tucker. The question is not whether the sentence could have been the same without consideration of the invalid convictions, but whether it would have. The inequity produced by the general appropriateness standard may be illustrated by a hypothetical situation. Suppose $A$ and $B$ are found guilty in federal court of the same bank robbery. $A$ is sentenced to five years, while $B$ is sentenced to ten years, the judge noting on the record that $B$ deserves a longer sentence because of his "long string of state robbery convictions that show his criminal depravity." Subsequently, all of $B$ 's state robbery convictions are held invalid under Gideon, and $B$ brings a Tucker petition in the sentencing court. The judge finds no Tucker violation because, for whatever reasons he may set forth, he finds that the ten-year sentence is still "appropriate" for $B$. Indeed, the sentence may well be appropriate for $B$, in light of current circumstances-perhaps $B$ has boasted to prison officials about the robberies he will commit when he is released, or perhaps current sentencing practices would find a ten-year sentence to be appropriate for a comparable bank robbery. But despite the appropriateness of the sentence, $B$ is still being treated unfairly. It is obvious from the record that, but for the consideration of the invalid robbery convictions, $B$ would have received a five-year term. The court considering the Tucker petition should strive to eradicate the harmful effects of the Gideon violation and put $B$ in the same position as $A$, whose sentence was not enhanced by any prior convictions.

Furthermore, even if the judge can honestly say that the sentencing judge (normally himself) would have imposed the ten-year sentence at the time of sentencing for reasons independent of the prior invalid convictions (that is, finding that such a sentence was "appropriate" even at the time of sentencing, despite the Gideon violations), he should still find a Tucker violation. Otherwise, the petitioner is in effect being forced to settle for a mere reconsideration of his sentence. In light of the advantages of resentencing over reconsideration, ${ }^{76}$ the slight burden on the courts, and the difficulty for even the same judge to say how he would have sentenced in the absence of the invalid convictions, a Tucker violation should be found whenever reliance on invalid convictions is shown. The Lipscomb test, although easy to apply,

${ }^{76}$ See text accompanying notes 79-88 infra. 
denies defendants the fairness that must be present in the vital sentencing process. This general appropriateness test should be rejected in favor of the strict harmless error test employed by the Ninth Circuit in Tucker. Such a strict test is necessary to counteract the harmful effects of the original Gideon violations.

One further issue must be addressed: the weight, if any, to be given by a reviewing court to the sentencing judge's statement that he did not rely on the challenged convictions in imposing sentence. The reviewing court should simply apply the strict harmless error rule and weigh the disclaimer along with the rest of the record. ${ }^{77}$ The reviewing court should not take lightly the sentencing judge's explicit disclaimer of reliance on invalid convictions, but neither should it give wide deference to such a disclaimer. The reviewing court should independently scrutinize the record in order to ascertain the rationale behind the sentencing decision. Where the record is devoid of any support for the petitioner's contention that consideration of the prior convictions enhanced his sentence, the disclaimer should suffice as grounds for denial of relief. If there is any support for the petitioner's position in the record, including the sentence itself and any statements made by the judge during sentencing, then the reviewing court should decide whether the sentencing judge's consideration of the defective convictions was harmless beyond a reasonable doubt. Of course, a trial judge's disclaimer made at the time of sentencing should be accorded more weight than one recited some time later.

Finally, in determining whether a Tucker violation has occurred, the courts should bear in mind the words of the Third Circuit: "Even though the statements of the sentencing judge do not explicitly reveal his consideration of the invalid sentences, we are of the opinion that the principles of Tucker are best effectuated by resolving any doubts we might have on this issue in favor of resentencing."78

\section{REMEDY FOR A TUCKER VIOLATION}

\section{A. Substance of the Remedy: Reconsideration or Resentencing?}

The language of the Supreme Court in affirming the Ninth Circuit's remand for resentencing in Tucker generated confusion

${ }^{77}$ Obviously, this solution is really applicable only in a reviewing court's assessment of the sentencing judge's denial of relief, because if a judge disclaims reliance, he will deny relief.

${ }^{78}$ United States ex rel. Fletcher v. Walters, 526 F.2d 359, 364 (3d Cir. 1975). 
over the precise remedy required for a Tucker violation. The Court spoke of both a "re-evaluation"79 and a "reconsideration" 80 of Tucker's sentence. Furthermore, in a footnote, the Court stated that "[i]t would be . . . callous to assume, now that the constitutional invalidity of the respondent's previous convictions is clear, that the trial judge will upon reconsideration 'undoubtedly' impose the same sentence he imposed in 1953."81 As a result of the Court's varying terminology, the lower courts have sometimes accepted a mere reconsideration, rather than a formal resentencing, to remedy Tucker violations. ${ }^{82}$

The first point to note about the less formal reconsideration remedy is its similarity to the appropriateness doctrine. The use of the appropriateness test may rest on either or both of two rationales. First, appropriateness is a means of disclaiming reliance: if the sentence is appropriate, then the sentencing judge could not have relied on invalid convictions in reaching his own decision. Secondly, if the sentence is appropriate, then a successful petitioner will merely have the same sentence re-imposed, and it is unnecessary to proceed with a formal resentencing. The theory of reconsideration is based upon this second rationale. This theory posits that if, given the appropriateness of the sentence, reconsideration would not warrant granting relief to a petitioner, then he has no right to a formal resentencing.

Reconsideration is less satisfactory than resentencing for two reasons. First, it lacks certain important procedural safeguards that resentencing provides. Second, reconsideration is less likely to result in thoroughly considered sentencing decisions than resentencing. The procedural safeguards at sentencing, though

${ }^{79}$ United States v. Tucker, 404 U.S. 443,448 (1972).

${ }^{80} \mathrm{Id}$. at 449 .

${ }^{81}$ Id. at 449 n. 8 .

${ }^{82}$ See, e.g., Wilson v. United States, 534 F.2d 130 (9th Cir. 1976); Hampton v. United States, 504 F.2d 600 (10th Cir. 1974); United States v. Simon, 488 F.2d 1094 (8th Cir. 1973) (per curiam), cert. denied, 417 U.S. 934 (1974). Such holdings have rested on two similar premises. First, in response to the Supreme Court's rejection of the assumption that the same sentence would be re-imposed on remand, United States v. Tucker, 404 U.S. $443,449 \mathrm{n.8}$ (1972), the courts have reasoned that, when the sentencing judge has clearly announced that the sentence would not be changed, even without consideration of the invalid convictions, then remand is clearly useless. See, e.g., United States v. Simon, 488 F.2d 1094 (8th Cir. 1973) (per curiam), cert. denied, 417 U.S. 934 (1974). Second, the courts have interpreted the Supreme Court's loose language to mean that a formal resentencing may not be necessary. Consequently, the judge has afforded an adequate remedy by his statement that he would not change the sentence. See, e.g., Wilson v. United States, 534 F.2d 130 (9th Cir. 1976). That the same sentence is reimposed is not, of itself, undesirable; but the re-imposition of the same sentence without the procedural safeguards and other benefits of a formal resentencing is to be condemned. See text accompanying notes 83-88 infra. 
relatively few, are crucial to a defendant. The federal system includes: the right of the defendant to be present at resentencing; ${ }^{83}$ the right to assistance of counsel, including counsel's right to speak on behalf of the defendant; ${ }^{84}$ and the defendant's right to make a statement on his own behalf and to present any information in mitigation of punishment. ${ }^{85}$ The defendant's right to speak allows him to present mitigating evidence and, to a limited extent, to challenge damaging evidence. In addition, it may be advantageous to the defendant if the judge faces him while meting out punishment. ${ }^{86}$ The right to counsel may be important in helping the defendant to utilize effectively the above rights, as well as in advising him of additional steps to take or objections to make during sentencing.

The second major failing of reconsideration is that it does not require the judge to address the problem of remedy as thoroughly as he would in the resentencing process. Without the procedural requirements and formality of the resentencing process, a judge may fail to give the defendant the searching inquiry and deep thought required in sentencing and will merely adhere to his original sentencing decision. Furthermore, certain aspects of the record may not be brought to the judge's attention if petitioner and his counsel are not present. These deficiencies in the reconsideration process may be aggravated in circuits that follow the general appropriateness approach to Tucker violations, ${ }^{87}$ because in those jurisdictions the sentencing judge reviews the sentence before deciding whether petitioner is entitled to any relief. In such cases the judge may incline towards a less rigorous review of the sentence than where the petitioner is already known to deserve some relief.

83 Fed. R. CRim. P. 43.

84 FED. R. CRIM. P. 32(a)(1). This right appears to be constitutionally required. Mempa v. Rhay, 389 U.S. 128 (1967); Note, Procedural Due Process at Judicial Sentencing for Felony, 81 HARv. L. REv. 821, 833-34 (1968).

85 FEd. R. CRIM. P. 32(a)(1). In Green v. United States, 365 U.S. 301, 304 (1961), the Court stated that the common-law right of allocution upon which Rule $32(a)$ is based requires that a defendant, and not merely his counsel, be given an opportunity to speak. But the failure of a trial court to ask a defendant represented by an attorney whether he wished to speak before sentence was imposed has been held not to be a per se constitutional violation of fundamental fairness that may be challenged under a writ of habeas corpus. Hill v. United States, 368 U.S. 424, 428 (1962). For a discussion of the common-law origin of the defendant's right to be present at sentencing and to speak on his own behalf, see Barrett, Allocution, 9 Mo. L. Rev. 115, 232 (1944). See also Annot., 96 A.L.R.2d 1292, 1295, 1307, 1317 (1964); Annot., 96 A.L.R.2d (Supp.) 369, 372 (1976).

${ }^{86}$ Note, Procedural Due Process at Judicial Sentencing for Felony, 81 HaRv. L. Rev. 821, 831 (1968).

${ }^{87}$ See note 73 supra. 
Because reconsideration fails to safeguard a petitioner's rights as fully as resentencing, reconsideration is an inadequate remedy for a Tucker violation. Sentencing, as discussed previously, is a critical stage of the criminal proceeding. The defendant is therefore entitled to the same type and degree of protections afforded at the trial itself. ${ }^{88}$ By comparison, when a verdict is invalidated, a judge or jury is not asked to state whether the petitioner would still be found guilty in light of the legal deficiency of the trial. A full retrial with all of its formal procedures is required. The same should certainly be true of sentencing-a stage that is crucial to the defendant and not nearly as burdensome on the court as a trial. When a sentence is vacated and the strict harmless error standard is not met, resentencing or its equivalent should be required.

\section{B. Requiring a New Judge for Resentencing}

If the appropriate remedy for a Tucker violation is a fullblown resentencing rather than a mere reconsideration of the original sentence, the issue remains whether a new judge should be required for resentencing. If the strict harmless error rule is to be applied, it is clearly advantageous for the original Tucker petition to be brought before the federal sentencing judge. Although some dangers may inhere in this procedure, he is in the best position to evaluate whether he relied on the invalid state convictions. ${ }^{89}$ He may also disclaim reliance and deny relief, however, forcing the Tucker petitioner to turn to a court of appeals. If the court of appeals then reverses a denial of relief based on its own examination of the record, the case should be remanded to a different judge for resentencing to permit the fairest assessment of an appropriate sentence untainted by consideration of a constitutionally infirm conviction.

In O'Shea $v$. United States ${ }^{90}$ the First Circuit was faced with a Tucker situation and remanded to the original sentencing judge. The court deviated from its usual practice of remanding cases (in non-Tucker situations) to new judges for resentencing. ${ }^{91}$ The

${ }^{88}$ See Mempa v. Rhay, 389 U.S. 128, 134 (1967); Note, Procedural Due Process at Judicial Sentencing for Felony, 81 Harv. L. Rev. 821,821 n.I (1968).

${ }^{89}$ See text accompanying note 95 infra.

90491 F.2d 774 (1st Cir. 1974).

${ }^{91}$ E.g., United States v. Bishop, 469 F.2d 1337, 1348 (1st Cir. 1972); United States v. Picard, 464 F.2d 215, 220 (1st Cir. 1972); Mawson v. United States, 463 F.2d 29, 31 (1st Cir. 1972) (per curiam). 
court first noted that familiarity with the case is relevant to appropriate sentencing, and that for a new judge to familiarize himself with the case would be wasteful..$^{92}$ The court then articulated the distinction between the Tucker situation and other resentencings. Reasoning that the original judge will have unique knowledge of relevant facts and will know how much weight he gave to the prior convictions, the court observed that "[i]f the issue is what would the defendant's original sentence have been if ... the presentence report had been appropriately limited [i.e., did not contain information of the invalid prior conviction], which, optimally is what the issue should be, no one but the original judge could normally answer that question."93

The court implicitly acknowledged that the function of the court hearing the Tucker petition was not merely to evaluate the appropriateness of the original sentence, declaring that "[i]f the issue were simply what would be an appropriate sentence on the revised record, a different judge could address the question "94 Reliance on a prior invalid conviction was instead the foremost issue to be determined by the court. Because the sentencing judge obviously knows the considerations behind his decision, he may conclude whether reliance did occur, thus entitling the petitioner to relief if the prior conviction is found to be invalid.

This procedure nevertheless generates some risks that were perceived in a different, but analogous, context by Judge Hufstedler of the Ninth Circuit Court of Appeals, dissenting in Wilson $v$. United States.$^{95}$ Addressing the issue of how much weight to give to a sentencing judge's disclaimer of reliance on certain factors, she recommended that cases involving Tucker violations be remanded to a new judge for resentencing. She argued that to ask the sentencing judge to reconsider his original decision called upon him "to undertake the intellectual gymnastics of trying to decide how he would have sentenced if he had known that he could not consider some of the information that he had earlier taken into account." Furthermore, even if the judge could perform such "gymnastics," Judge Hufstedler found such a procedure faulty because it would be "perceived as unfair." Finally, she concluded that "judges are susceptible to that frailty of

\footnotetext{
92491 F.2d at 779.

${ }^{93} I d$.

${ }^{94} \mathrm{Id}$. (emphasis in original).

95 534 F.2d 130 (9th Cir. 1976).
} 
human-kind to stick to a judgment, once uttered, even when later shown that it was wrong." 96

The $O$ 'Shea rationale does provide a justification for initially requiring the petitioner to present his motion to the sentencing judge whenever possible. But because of the reasons pointed out by Judge Hufstedler, a reviewing court should not be overly deferential to the sentencing judge's disclaimer. One potential problem is that district judges will routinely find a Tucker violation, but then, just as routinely, reimpose the original sentence. To forestall such a practice, the courts of appeals might require the district judges to announce reasons for not reducing such sentences. If the routine reimpositions persist, the courts of appeals should remand Tucker petitions to a judge other than the original sentencing judge.

The O'Shea rationale seems less applicable, however, where the sentencing judge has denied petitioner's motion on the ground that he did not rely on the allegedly improper information in imposing the original sentence and the court of appeals has reversed, finding a reasonable probability of reliance. In such a case, whatever benefit is to be derived from the sentencing judge's familiarity with the case and with the reasons for his original sentencing decision have already been derived. Consequently, nothing will be gained by remanding to him for resentencing. Considerations of fairness mandate that such a case be remanded to a new judge for resentencing.

\section{Conclusion}

This Comment has examined the Tucker rule, and has proposed certain procedures for its implementation. The discussion has considered the proper procedures for cases in which a federal sentence is increased by consideration of prior state convictions that are invalid under Gideon $v$. Wainwright. ${ }^{97}$ In summary, the suggested Tucker procedure is as follows:

(1) The initial petition alleging that a federal sentencing

${ }^{96}$ Id. at 138 (citations omitted) (Hufstedler, J., dissenting). Although no other court has explicitly considered the question in the Tucker context, several courts have, in other contexts, followed the First Circuit's practice of remanding cases to different judges for resentencing. See, e.g., United States v. Hammerman, 528 F.2d 326 (4th Cir. 1975); United States v. Huff, 512 F.2d 66 (5th Cir. 1975); United States v. Schwarz, 500 F.2d 1350 (2d Cir. 1974) (per curiam); United States v. Vale, 496 F.2d 365 (5th Cir. 1974); of. Santobello v. New York, 404 U.S. 257 (1971) (if resentencing were found, on remand, to be appropriate remedy for prosecutorial misconduct in breaching agreement not to make sentencing recommendation, resentencing should be by a different judge).

${ }^{97} 372$ U.S. 335 (1963). 
judge relied upon a prior invalid state conviction should be presented to the original sentencing judge whenever practicable, without any requirement of prior invalidation of the allegedly invalid convictions and without any requirement that those convictions be invalidated in the states imposing them.

(2) The judge hearing the petition should apply a strict harmless error test (rather than a general appropriateness test) to determine whether the sentencing judge (including himself) relied on the allegedly invalid state convictions in imposing the federal sentence.

(3) If the judge determines beyond a reasonable doubt that consideration of the prior state convictions did not affect the federal sentence, he should deny the Tucker petition. Otherwise, he should hold an evidentiary hearing to determine the validity of the prior state convictions. (Alternatively, he may rule on the validity of those convictions before proceeding to the reliance inquiry.)

(4) If any of the prior state convictions is determined to be invalid, the petitioner should be afforded a full resentencing.

(5) A court of appeals reviewing a denial of a Tucker petition by the original sentencing judge should assess that judge's decision in light of the record, using a strict harmless error test.

(6) If the court of appeals concludes that the allegedly invalid state convictions might have affected the original sentence, the case should be remanded to a judge other than the original sentencing judge for an evidentiary hearing on the validity of the prior convictions, and for a full resentencing, if warranted. In some cases the invalidity of the state convictions will appear on the face of the record, in which case the remand will be for resentencing only.

The use of such procedures will help to insure that a criminal defendant will not be additionally penalized because of unconstitutionally obtained convictions. 